\title{
First-year experience of a new skin bank in Brazil
}

\section{Alysson Rogerio Matioski, Clóvis Rodrigo Guimarães Braz Pereira da Silva, Diogo Rodrigues da Silva-Cunha, Luiz Henrique Auerswald Calomeno, Flávia Thaiana Bonato, Marcelus Vinícios Araujo Nigro}

Department of Burn and Plastic Surgery, Evangelical University Hospital of Curitiba, Curitiba, Paraná 80730150, Brazil.

Address for correspondence: Dr. Alysson Rogerio Matioski, Department of Burn and Plastic Surgery, Evangelical University Hospital of Curitiba, Curitiba, Paraná 80730150, Brazil. E-mail: alymatioski@yahoo.com.br

\begin{abstract}
Aim: To report the 1st year experience of the skin bank opened at the Evangelical University Hospital of Curitiba (HUEC), Brazil in June 2013. Methods: A retrospective statistical and epidemiological study was conducted from data obtained from the activities of the HUEC skin bank from June 2013 to August 2014. Results: The HUEC skin bank harvested tissue from 45 cadaveric donors $(46.6 \%$ female and $53.3 \%$ male), with an average age of 36.42 . The white skin-colored donors represented $91 \%$ of donations. Most causes of death were of neurological origin (55.6\%). Eighty-one batches were harvested. The bank processed 31,314.63 $\mathrm{cm}^{2}$ of skin for transplantation (41 batches), and 38 batches were discarded. The distributed allografts totaled $28,940.82 \mathrm{~cm}^{2}$, with tissue from a single donor benefitting up to 5 patients. A total of 52 transplant procedures were performed $(66.6 \%$ of recipients were male and $33.3 \%$ female), burn victims represented $83.3 \%$ of the recipients. Conclusion: The HUEC skin bank provides skin primarily for victims with severe third-degree burns, mostly men, and who are treated and transplanted in the HUEC as a result of high demand. The successful outcomes highlight the potential use for other clinical indications.
\end{abstract}

Key words:

Allograft, Brazil, burns, donation, Evangelical University Hospital of Curitiba, skin, skin bank

\section{INTRODUCTION}

Burns are an important public health problem. ${ }^{[1]}$ In Brazil, it is estimated that they are the cause of approximately $1,000,000$ accidents per year. Of these, 100,000 patients will require hospital care, and about 2,500 will die directly or indirectly as a result of their injuries. ${ }^{[2]}$ One of the best ways to treat burn patients is by the use of allografts, which remain the biological dressing of choice and are an important tool. In many cases they can be used for the effective reconstruction of the dermal component. ${ }^{[3]}$

\begin{tabular}{|l|l|}
\hline \multicolumn{2}{|c|}{ Access this article online } \\
\hline Quick Response Code: & Website: \\
\hline & www.parjournal.net \\
\hline & \\
\hline
\end{tabular}

Although allografts are primarily used in the treatment of severe burns, they can also be used for many indications, including extensive skin loss, surgical wounds, lower limb ulcers, pyoderma gangrenosum of diabetic feet and bullous diseases. In addition to serving as a barrier against infection, allografts serve as a temporary biological dressing to help control pain, protect deep structures, promote re-epithelialization and restore the important functions of the skin such as thermal regulation and

This is an open access article distributed under the terms of the Creative Commons Attribution-NonCommercial-ShareAlike 3.0 License, which allows others to remix, tweak, and build upon the work non-commercially, as long as the author is credited and the new creations are licensed under the identical terms.

For reprints contact: reprints@medknow.com

How to cite this article: Matioski AR, da Silva CR, da Silva-Cunha DR, Calomeno LH, Bonato FT, Nigro MA. First-year experience of a new skin bank in Brazil. Plast Aesthet Res 2015;2:326-31.

Received: 20-03-2015; Accepted: 06-09-2015 
control of fluid loss. ${ }^{[4-7]}$ For these reasons, their use results in a significant reduction in hospital stay and mortality rates, and may generate cost savings. ${ }^{[4]}$

In 1949, the first skin bank was established by the US Navy. Since then, several other skin banks have been founded, mostly in the USA and Europe and often organized as multi-tissue banks. In 2005, there were approximately 54 active skin banks in the North America. ${ }^{[5]}$ Currently, there are four skin banks in Brazil, based in São Paulo, Porto Alegre, Recife and Curitiba city. ${ }^{[7]}$ The latter is the skin bank of the Evangelical University Hospital of Curitiba (HUEC), which officially opened on June 17, 2013 and the activity of which is the focus of this study.

In 2013, the plastic surgery and burns service of the Evangelical Hospital in Curitiba located in Paraná state provided medical attention to approximately 4,500 burn victims of which at least $10 \%$ required hospitalization with the potential indication for skin use; this demonstrated the importance of establishing a skin bank within this hospital. The objective of this study is to report the 1 st year experience of the Evangelical Hospital of Curitiba skin bank.

\section{METHODS}

Retrospective epidemiological and statistical data were collected during the 1st year of operations, from June 2013 to August 2014. The study was approved by the Research Ethics Committee of the Evangelical Beneficent Society of Curitiba, Brazil.

Collected information included two different tissue banking aspects. The first includes data on skin retrieval between June 27, 2013 and June 26, 2014 and the second data set corresponds to skin distribution and transplantation between August 28, 2013 and August 27, 2014.

Data were obtained from analysis of the bank's records of cadaveric (multi-organ/skin tissue) donation and tissue distribution, including a review of the necessary documentation on the cause of death and organ donation.

Inclusion criteria were all medical records of donors of harvested skin and all recipients who received grafts during the 1 st year of the bank. There were no exclusion criteria.

The data collected concerning the deceased donors included: age, gender, skin color, cause of death, thickness of retrieved skin tissue $(\mathrm{mm})$, body region from which the skin was removed, number of generated skin batches, hospital where the skin retrieval occurred, date of skin retrieval, area $\left(\mathrm{cm}^{2}\right)$ of retrieved skin, reason of skin discards when unfit for use and the number of benefited patients from each donor.

As for the skin recipients, collected data included: age, gender, hospital where the allografts were used, donor to recipient ratio, area of allografted skin $\left(\mathrm{cm}^{2}\right)$, graft release date, body region receiving the allografts and indication for allograft use. In burn victim recipients, additional data collected included the extent of the burnt region and burn depth.

According to the Brazilian skin donation protocol, the steps are as follows: (1) Paraná State Transplantation Center calls about a potential donor, and the skin bank staff goes to the donor site hospital; (2) a physical examination of the donor is performed to assess the quality of the skin area to be harvested; (3) the donor's medical and family history are screened to elicit any history of (a) ingestion of toxic or illicit drugs; (b) high-risk sexual behavior, recent invasive procedures, malignancies, chronic diseases, death from an unknown cause, infectious disease, immunocompromise and surgical procedures occurring within the prior 12 months; and (c) donor age, which is limited to between 14 years old and 60 years old; (4) blood samples are collected from the donor $72 \mathrm{~h}$ prior to cessation of circulation, $12 \mathrm{~h}$ after the cessation of blood flow if the body has been kept at room temperature, or up to $24 \mathrm{~h}$ after the cessation of blood flow if the body has been cooled to $4{ }^{\circ} \mathrm{C} \pm 2{ }^{\circ} \mathrm{C}$. The tissues cannot be released for use until final results have been obtained. When tests for HIV and hepatitis C virus (HCV) are negative, further testing is performed for RNA detection of HIV and HCV. Mandatory serological donor screening is performed to detect the following: (a) hepatitis B (hepatitis B surface antigen and anti-hepatitis B core), (b) anti-HCV, (c) HIV-1 and HIV-2 (HIV 1 and 2), (d) Chagas disease (anti-Trypanosoma cruzi), (e) syphilis (one treponemic or nontreponemic test), (f) human T-lymphotropic virus type I (HTLV-I) and HTLV-II (anti-HTLV I and II), (g) toxoplasmosis (toxoplasma $\operatorname{lgG}$ and $\operatorname{IgM}$ ), and (h) cytomegalovirus (IgG and anti-IgM); (5) the donor is accepted once all laboratory tests have been confirmed to be normal; (6) skin harvest is then performed for a thickness of $0.4-0.8 \mathrm{~mm}$. The skin blade is passed to the nurse who takes swab and inoculates it in thioglycolate broth, amid Sabouraud broth and trypticase soy broth (TSB) respectively, then the nurse dips the blade in $0.9 \%$ saline solution twice prior to immersion in glass with glycerol $90 \%$; and (7) the stored skin is processed in a sterile laminar flow hood in 3 phases: Phase 1: skin is removed from the shipping bottle. Then 2 fragments of $0.5 \mathrm{~cm} \times 0.5 \mathrm{~cm}$ of each blade are withdrawn for microbiological analysis. Each fragment must be macerated and inoculated in thioglycolate broth, Sabouraud medium, TSB broth and blood culture bottle for aerobic and anerobic germs. The skin blades are stored again in new bottles with glycerol 90\% sterile; the vials with the skin in $90 \%$ glycerol are placed in water bath at $37{ }^{\circ} \mathrm{C}$ for $3 \mathrm{~h}$, then removed from water bath and stored in tissues not released refrigerator; Phase 2: if the first phase microbiological analysis is negative for any germs (waiting time: 15 days) the second phase is performed like the first one; and Phase 3: if the second phase microbiological analysis is negative for any germs (waiting time: 15 days) the third phase is performed like previous phases with removal of excess of glycerol; thereafter, the blades are placed in a sterile plastic bag 
and kept refrigerated. The skin is measured and released after the third negative microbiological results.

The batch is discarded should there be positive culture results with any germs in any of the phases. The discarded skin is not counted, as measurements are carried out only following the final phase.

Cryopreservation was not used as the skin was stored in a refrigerator at $4{ }^{\circ} \mathrm{C} \pm 2{ }^{\circ} \mathrm{C}$. The skin is maintained in a $90 \%$ sterile glycerol solution prior to packaging. All allografts were nonmeshed.

\section{RESULTS}

In its 1 st year of operation, the skin bank of the HUEC retrieved skin tissue from 45 cadaveric donors (46.6\% female and $53.3 \%$ male) with an average age of 36.4 years (range: $15-60$ years).

Most donors were Caucasian (91\%); there were no donations from black or yellow skin-colored donors. The most frequent cause of death was of neurological origin, with traumatic brain injury and stroke accounting for $55.6 \%$ of cases.

Data related to gender, age, race and cause of death is presented in Table 1 below.

All skin tissue retrievals took place in hospitals within Curitiba city, with $44 \%$ in the HUEC, followed by other major trauma hospitals [Table 2].

Regarding the use of donated skin, tissue from $48.9 \%$ of donors was released for clinical application. Tissue

Table 1: Skin donors profile

\begin{tabular}{|c|c|}
\hline Variable & Descriptive statistics $n(\%)$ \\
\hline \multicolumn{2}{|l|}{ Gender } \\
\hline Female & $21(46.67)$ \\
\hline Male & $24(53.33)$ \\
\hline Total & $45(100.00)$ \\
\hline \multicolumn{2}{|l|}{ Age (in years) } \\
\hline Average ( $\pm \mathrm{SD})$ & $36.42(5)$ \\
\hline Maximum & 60 \\
\hline Minimum & 15 \\
\hline \multicolumn{2}{|l|}{ Skin color } \\
\hline White & $41(91.11)$ \\
\hline Brown & $4(8.89)$ \\
\hline \multicolumn{2}{|l|}{ Cause of death } \\
\hline Severe TBI & $13(28.89)$ \\
\hline Stroke & $12(26.67)$ \\
\hline Polytrauma & $7(15.56)$ \\
\hline $\mathrm{CHF}^{*} /$ respiratory insufficiency & $3(6.67)$ \\
\hline $\mathrm{WGF}^{\dagger}$ & $3(6.67)$ \\
\hline Preeclampsia & $1(2.22)$ \\
\hline NW & $1(2.22)$ \\
\hline Lung cancer & $1(2.22)$ \\
\hline HÁ§ & $1(2.22)$ \\
\hline Chronic pancreatitis & $1(2.22)$ \\
\hline Suicide & $1(2.22)$ \\
\hline Dissecting aneurysm & $1(2.22)$ \\
\hline
\end{tabular}

*Congestive heart failure, ${ }^{\dagger}$ Wound by gunfire, ${ }^{*}$ Knife wound, ${ }^{\circledR}$ Heart attack, SD: Standard deviation, TBI: Traumatic brain injury from $42.2 \%$ of donors had to be discarded secondary to contamination, and $6.7 \%$ of tissues were partially discarded. At the end of the period, tissue from one donor ( 2 batches) was still under quarantine [Table 2]. Eighty-four point four percent of retrievals of skin were from the back and lower limbs, as specified in Table 2.

The total amount of collected skin tissue during the period of evaluation was $31,314.63 \mathrm{~cm}^{2}$. The largest amount of retrieved tissue from a single donor totaled $2,453.6 \mathrm{~cm}^{2}$ and the lowest amount was $422.2 \mathrm{~cm}^{2}$. The obtained average amount was $1,252.59 \mathrm{~cm}^{2}$ per donor, as shown in Table 3 .

Tissues retrieved from the 45 donors generated 81 processing batches in the 1st year of operation; 41 were of acceptable quality for clinical use, 38 were discarded due to an unacceptable biological burden, and 2 remained in quarantine at the end of the period. Thirty-eight of the batches released for use were transplanted and 3 remained in storage [Table 3].

Fourty-two point one percent of tissue discard was due to detection of coagulase-negative staphylococci. Two batches from a single donor were positive for more than one contaminant. Reasons and contaminants of discarded tissues are specified in Table 3.

As observed in Table 4, tissues from a single donor benefited up to 5 patients. A total of 30 patients received tissue during this period.

Table 2: Skin tissue retrieval

\begin{tabular}{|c|c|}
\hline Variable & $\begin{array}{c}\text { Descriptive } \\
\text { statistics [ } n(\%)]\end{array}$ \\
\hline \multicolumn{2}{|l|}{ Institution } \\
\hline Evangelical University Hospital of Curitiba & $20(44.44)$ \\
\hline Cajuru University Hospital & $8(17.78)$ \\
\hline Workers $\times$ Hospital & $6(13.33)$ \\
\hline São Vicente Hospital & $3(6.67)$ \\
\hline Vitória Hospital & $1(2.22)$ \\
\hline Angelina Caron Hospital & $1(2.22)$ \\
\hline Pilar Hospital & $1(2.22)$ \\
\hline Nations' Hospital & $1(2.22)$ \\
\hline Zilda Arns Hospital for Elderly & $1(2.22)$ \\
\hline Red Cross Hospital & $1(2.22)$ \\
\hline UFPR* Clinical Hospital & $1(2.22)$ \\
\hline Vita Batel Hospital & $1(2.22)$ \\
\hline Total & $45(100.00)$ \\
\hline \multicolumn{2}{|l|}{ Donor areas } \\
\hline Back and legs (anterior and posterior) & $38(84.44)$ \\
\hline Lower limbs (anterior and posterior) & $5(11.11)$ \\
\hline Abdomen and legs (anterior and posterior) & $2(4.44)$ \\
\hline \multicolumn{2}{|l|}{ Retrieved tissue outcomes (number of donors) } \\
\hline All tissues acceptable for use & $22(48.89)$ \\
\hline All tissues discarded & $19(42.22)$ \\
\hline Partial discard & $3(6.67)$ \\
\hline Skin still being processed & $1(2.22)$ \\
\hline \multicolumn{2}{|l|}{ Areas (in $\mathrm{cm}^{2}$ ) of retrieved skins tissue } \\
\hline Total & $31,314.63$ \\
\hline Maximum per donor & $2,453.60$ \\
\hline Minimum per donor & 422.20 \\
\hline Average per donor $( \pm S D)$ & $1,252.59(530.38)$ \\
\hline
\end{tabular}

*The Federal University of Paraná, SD: Standard deviation 
The average age and sex of tissue recipients is depicted in Table 5.

Thirty patients underwent a total of 52 transplants; $88.5 \%$ of the transplants were performed at the HUEC, $7.7 \%$ were performed at the Regional University Hospital of Northern Paraná in Londrina city, 2\% at the Vita Batel Hospital of Curitiba and $2 \%$ at the São Paulo Regional Hospital in Santa Catarina state [Figure 1].

A total allograft area of $28,940.83 \mathrm{~cm}^{2}$ was transplanted, with the largest area grafted in a single procedure at $1,816.4 \mathrm{~cm}^{2}$ and the smallest at $68 \mathrm{~cm}^{2}$. The largest amount of tissue grafted to a single patient was $7,284.75 \mathrm{~cm}^{2}$. A single patient could receive skin from up to 10 donors, with an average of 3 donors and a minimum of one donor per surgical intervention [Table 6].

Most patients who received allografts were burn victims, corresponding to 25 patients and 45 skin transplantation procedures. The indications for the other 7 transplants are shown in Figure 2.

Among the burn victims, the vast majority (96\%) presented with third-degree burns. The most extensively compromised body surface area was $75 \%$ and the lowest $10 \%$, with an average of $38.64 \%$ of the total body surface area [Table 7].

The body areas which were transplanted are shown in Table 8.

Table 3: Batches of generated skin

\begin{tabular}{lcc}
\hline Variable & \multicolumn{2}{c}{ Descriptive statistics } \\
\cline { 2 - 3 } & Batch number & Percentage \\
\hline Quantity (number of batches) & & \\
$\quad$ Approved for distribution & 38 & 4.91 \\
$\quad$ Transplanted & 3 & 3.70 \\
$\quad$ Stored in the bank & 38 & 46.91 \\
Discarded & 2 & 2.47 \\
In process quarantine & 81 & 100.00 \\
Total & & \\
Reasons for batch discard & 16 & 42.11 \\
Growth of coagulase-negative & & \\
staphylococci & 7 & 18.42 \\
Growth of bacillus & & \\
Gram-positive not Clostridium & 6 & 15.79 \\
Growth of filamentous Fungi & 4 & 10.53 \\
Growth of positive coagulase & & \\
Staphylococcus & 3 & 7.89 \\
Growth of Enterococcus spp. & 2 & 5.26 \\
Positive for syphilis & 2 & 5.26 \\
Lung cancer & 40 & 105.26 \\
Total & & \\
\hline
\end{tabular}

Table 4: Relation between benefited patients and donors

\begin{tabular}{lc}
\hline & $\boldsymbol{n}$ \\
\hline Total of benefited patients & 30 \\
Average of benefited patients per donor ( \pm SD) & $2.36(1.35)$ \\
Maximum of patients benefited per donor & 5 \\
\hline
\end{tabular}

SD: Standard deviation

\section{DISCUSSION}

The HUEC skin bank collected tissue from 45 cadaveric donors during its 1 st year of operation. Upon a review of the Brazilian literature, a number of similar collections were noted from another operational skin bank. ${ }^{[8]}$ The numbers in this study compare favorably with available international data. ${ }^{[9]}$ Of great importance was the ability of the HUEC skin bank to address the local demand.

The average age of the skin donors was similar to that of the donors of the Helsinki skin bank ${ }^{[9]}$ but lower than the average age of donors to the Porto Alegre skin bank. ${ }^{[8]}$ The higher number of younger donors may be justified by the higher mortality rates within this cohort in the city of Curitiba due to traffic accidents and physical assaults, which were 23.2 and 42.1 per 100,000 inhabitants, respectively, according to the information department of Unified Health System (DATASUS 2008). ${ }^{[10]}$

An equal number of women and men were donors, despite the number of deaths from external causes in 2012 being 3.36 times higher for males in Curitiba. ${ }^{[1]}$

The vast majority of donors in Curitiba were of white-colored skin, justified by a predominantly Caucasian population in the region. According to Database of Unified Health System of Brazilian government (DATASUS) ${ }^{[11]}$ recordson mortality in Curitiba in 2012, 8,218 white skin people died as compared

Table 5: Recipients profile

\begin{tabular}{lc}
\hline Variable & Descriptive statistics $\boldsymbol{n}(\%)$ \\
\hline Gender & $10(33.33)$ \\
Female & $20(66.67)$ \\
Male & $30(100.00)$ \\
Total & \\
Age & 29.09 years $(22.72)$ \\
Average $( \pm$ SD) & 85 years \\
Maximum & 18 days \\
Minimum &
\end{tabular}

Table 6: Grafted skin

\begin{tabular}{lc}
\hline Variable & Descriptive statistics $(\boldsymbol{n})$ \\
\hline Transplanted skin area $\left(\right.$ in $\left.\mathrm{cm}^{2}\right)$ & \\
Total & $28,940.82$ \\
Maximum per surgery & $1,816.4$ \\
Minimum per surgery & 68 \\
Maximum per patient & $7,284.75$ \\
Minimum per patient & 68 \\
Average per surgery & 556.55 \\
Average per patient & 964.694 \\
Relation between donors $\times$ recipients & \\
Maximum of donors per patient & 10 \\
Maximum of donors per surgery & 3 \\
Minimum of donors per patient & 1 \\
Minimum of donors per surgery & 1 \\
Average of donors per patient & 1.93 \\
Average of donors per surgery & 1.25 \\
\hline
\end{tabular}




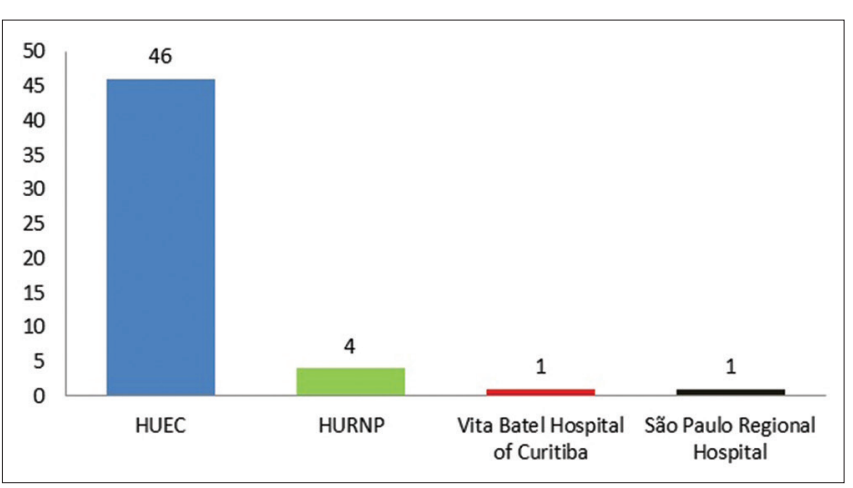

Figure 1: Number of allograft procedures by institutiont

Table 7: Degree and extension of burns

\begin{tabular}{lcc}
\hline Variable & \multicolumn{2}{c}{ Descriptive statistics } \\
\cline { 2 - 3 } & Patients number & Percentage \\
\hline Burn depth & 20 & \\
Only third-degree & 4 & 80.00 \\
Second and third-degree & 1 & 16.00 \\
Only deep second degree & 25 & 4.00 \\
Total & & 100.00 \\
Compromised body area (\%) & 2 & \\
75 & 1 & 8.00 \\
65 & 1 & 4.00 \\
56 & 1 & 4.00 \\
48 & 7 & 4.00 \\
45 & 1 & 28.00 \\
40 & 1 & 4.00 \\
38 & 1 & 4.00 \\
36 & 3 & 4.00 \\
35 & 3 & 12.00 \\
20 & 1 & 12.00 \\
18 & 1 & 4.00 \\
15 & 2 & 4.00 \\
10 & & 8.00 \\
\hline
\end{tabular}

Table 8: Transplanted body areas

\begin{tabular}{lc}
\hline Variable & Descriptive statistics $\boldsymbol{n}$ (\%) \\
\hline Allograft region (recipients) & \\
Lower limb & $18(60.00)$ \\
Thorax & $18(60.00)$ \\
Upper limb & $14(46.67)$ \\
Back & $8(26.67)$ \\
Face & $7(23.33)$ \\
Cervical & $3(10.00)$ \\
Abdomen & $2(6.67)$ \\
Perineum & $1(3.33)$ \\
Buttocks & $1(3.33)$ \\
Genitalia & $1(3.33)$ \\
\hline
\end{tabular}

to 257 people with black skin and 59 with yellow skin. Interestingly, there were no black or yellow skin donors, raising the possibility that social, cultural and educational factors within this population cohort may have influenced the consent outcomes for skin donation.

Almost half of the skin donation consents were obtained at the HUEC where the skin bank is located. This outcome

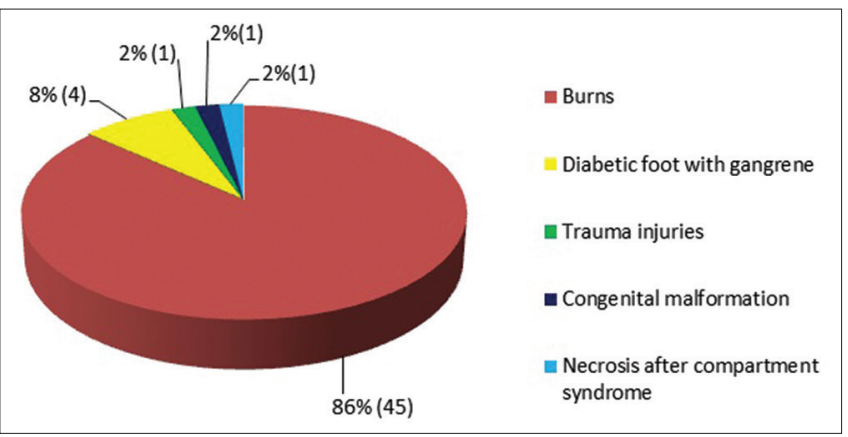

Figure 2: Relation between transplants and allografts reasons

generated some questions: was there a greater awareness of families from potential donors, who were able to observe the care of many burned patients during their own hospital experience? Was the team that approached families of potential donors at the HUEC better prepared to explain skin donation and demystify this procedure, still rarely performed in Brazil? This and possible additional factors should be analyzed to understand why the number of donors in other major trauma hospitals in the region were lower when compared to those from HUEC. Because the offer to donate is provided to the same population, the outcomes could be decisive in increasing the rates of skin donation and transplantation.

During this 1 st year of operation, changes were made in the thickness of the retrieved skin. Until February 2014, the grafts harvested were between $0.7 \mathrm{~mm}$ and $0.8 \mathrm{~mm}$ in thickness. Increased experience in collection and use of the allografts demonstrated that, for better integration, the tissue should have a thickness of $0.4 \mathrm{~mm}$ despite the somewhat more complicated and time-consuming manipulation.

The number of discarded tissue batches was high, surpassing by approximately $30 \%$ the discard rates at the Porto Alegre skin bank from 2008 to 2012. ${ }^{[8]}$ In contrast to other national and most international skin banks, the HUEC skin bank protocols did not include exposure of the harvest skin to antibiotics or other disinfecting agents, mainly due to high costs. The data obtained has led to a view of the protocols, in particular, considering that quite a significant number of donors had been hospitalized in the Intensive Care Unit and thus highly manipulated. The goal is to mimic the outcomes of the Helsinki bank, where no batch has been discarded for 8 years. ${ }^{[9]}$

On analysis of the skin made available for transplantation, the retrieved skin area amounted to $31,314.63 \mathrm{~cm}^{2}$, which is a small number when compared to the skin bank of Helsinki, which scored an average of 44,335 $\mathrm{cm}^{2}$ per year from 2001 to 2008..$^{[9]}$ This was higher than the Clinical Hospital in São Paulo which raised approximately $153,000 \mathrm{~cm}^{2}$ of tissue from 2001 to 2006. ${ }^{[7]}$ Comparing the average area, the HUEC accounted for $1,252.59 \mathrm{~cm}^{2}$ of retrieved tissues per donor, a number compatible with that obtained by the bank of Porto Alegre, ${ }^{[12]}$ but still far below that of the Helsinki bank.

One deviation from acceptance criteria was identified during the retrieval process, when a lung cancer donor 
had skin collected, despite this being a contraindication to skin donation. The tissue was subsequently discarded.

As reported by other skin banks, the HUEC skin bank distributed most of its collected tissue to burn victims, corresponding to 25 of the 30 recipients and $86 \%$ of transplants performed. This statistic is readily explained by the skin bank's location within a referral center for the treatment of burn patients. Another explanation for these numbers is the relative decreased awareness by other medicals specialists whose patients could benefit from the use of skin allografts (e.g. vascular ulcers).

Comparing the Brazilian epidemiology of burn patients, this study found that $80 \%$ of recipients experienced exclusively third-degree burn injuries. A different result was obtained by Montes et al. ${ }^{[13]}$ who found that $88.4 \%$ of burn patients had only second-degree injuries. This difference is likely secondary to HUEC's treatment of burn victims with deep and large burns. In a literature review of burn victims in Brazil, de Cruz et al. ${ }^{[14]}$ found that the average burnt body surface area was $14.6 \%$. This study demonstrated a higher average of burnt surface area per recipient (38.84\%), perhaps because the use of allograft skin was prioritized for critically ill patients with less possibility for autografting.

In this study, it was observed that $28,940.83 \mathrm{~cm}^{2}$ of skin was grafted in HUEC with an average of $964.69 \mathrm{~cm}^{2}$ per patient; these were higher numbers as compared to the bank of Porto Alegre which sent $35,415 \mathrm{~cm}^{2}$ of skin to be grafted onto burn patients nationwide. ${ }^{[12]}$ This variation may reflect a different indication profile in the hospital burn service, as $88.5 \%$ of transplants occurred at our hospital secondary to high demand by locally admitted burn patients.

The HUEC skin bank provided skin for 30 patients. This result is proportional to that of the Porto Alegre skin bank. ${ }^{[8]}$ Noting that the skin from a single donor benefitted up to 5 patients, with an average of 2.36 recipients per donor, the benefits of a skin bank are clear.

It was observed that the number of retrievals made and the skin area collected by our service was compatible with that seen at other national and international databases, which are in some cases restricted or difficult to access.

Although our use was comparable to these banks, the high disposal rates at our center demonstrate that there is room for improvement in our collection and processing techniques. Techniques including radiosterilization of contaminated tissues, exposure to antibiotics, and better use of the antimicrobial properties of glycerol are being studied for future use to reduce the rate of contaminated tissue.

The HUEC skin bank provided skin primarily for victims of severe third-degree burns, mostly men, who were treated and transplanted in HUEC. This elevated domestic demand prevented us from sending skin to other regions of the country, highlighting a great need for donations and an improved collection process.

The albeit limited but successful local experience in allograft application for other indications beyond burn care highlights the importance of sharing the potential benefits of allograft availability and use in other medical areas.

A single skin tissue donor can benefit several patients, this should motivate an increase in the profile of skin donation within the public organ and tissue donation campaigns. Both an increased awareness of the importance of donation and the possibility to save several lives, as well as reducing misconceptions of body disfigurement due to skin donation, should be considered.

\section{Financial support and sponsorship}

Nil.

\section{Conflicts of interest}

There are no conflicts of interest.

\section{REFERENCES}

I. Roch HJ, Lira SV, de Abreu RN, Xavier ÉP, de Vieira LJ. The profile of accidents by hot liquids in children attended at a reference center in Fortaleza. Rev Bras Promoção Saúde 2007;20:86-91.

2. Crisóstomo MR, Serra MC, Gomes DR. Epidemiology of burns. In: Maciel E, Serra MC, editors. Treaty Burns. Rio de Janeiro: Atheneu; 2004. p. 31-5.

3. Pianigiani E, lerardi F, Cherubini Di Simplicio F, Andreassi A. Skin bank organization. Clin Dermatol 2005;23:353-6.

4. Fimiani M, Pianigiani E, Di Simplicio FC, Sbano P, Cuccia A, Pompella G, De Aloe G, Petraglia F. Other uses of homologous skin grafts and skin bank bioproducts. Clin Dermatol 2005;23:396-402.

5. Kagan RJ, Robb EC, Plessinger RT. Human skin banking. Clin Lab Med 2005;25:587-605.

6. Junqueira JJ, Eras AE, Polo EF, Herson MR, dos Santos VA. Incidence of seropositivity for cytomegalovirus in skin graft donors at the skin bank of the university of the São Paulo Medical School. J Bras Transplantes 2007; 10:717-9.

7. Schiozer W. Skin banking in Brazil. Rev Bras Queimaduras 2012; I 1:53-5.

8. da Silveira DP, Rech DL, Pretto Neto AS, Martins AL, Ely PB, Chem EM. Skin Bank of Porto Alegre: produtivity and donors profiles. Rev Bras Cir Plást 20I3;28:6.

9. Lindford AJ, Frey I, Vuola J, Koljonen V. Evolving practice of the Helsinki skin bank. Int Wound J 2010;7:277-8I.

10. Health Information Notebooks, 2010. Brasília: Ministério da Saúde; 2010. Available from: http://www.tabnet.datasus.gov.br/tabdata/cadernos/ pr.htm. [Last accessed on 2014 Nov 02].

II. System of Mortality Information, 20I2. Brasília: Ministério da Saúde; 2012. Available from: http://www.tabnet.datasus.gov.br/cgi/tabcgi.exe?sim/cnv/ obt I0pr.def. [Last accessed on 2015 Jan 07].

12. Minuzzi Filho AC, Chem E, Ely PB, Valiati AA, Fauri M, Cunha TF. Statistics of the santa casa of porto alegre hospital complex skin bank, years 2008-20I0. Rev Bras Cir Plást 2010;25:93.

13. Montes SF, Barbosa MH, de Sousa Neto AL. Clinical and epidemiological aspects of burned patients hospitalized in a teaching hospital. Rev Esc Enferm USP 2011;45:369-73.

14. de Cruz B, Cordovil PB, de Batista K. Epidemiological profile of patients who suffered burns in Brazil: literature review. Rev Bras Queimaduras 20I2; I I:246-50. 